\title{
IMPACT OF DIETARY SUPPLEMENTATION WITH MULTI-ENZYME AND/OR PROBIOTICS ON PRODUCTIVE PERFORMANCE AND NUTRIENTS DIGESTIBILITY OF BROILER CHICKENS.
}

\author{
M. I. El-Kelawy ${ }^{1}$, A. S. El-Shafey ${ }^{2}$, and Reham M. Ali ${ }^{3}$ \\ ${ }^{1}$ Department of Poultry Production, Faculty of Agriculture (New Valley), Assiut University, Egypt. \\ ${ }^{2}$ Department of Animal and Poultry Production, Faculty of Agriculture, Damanhour University, Egypt \\ ${ }^{3}$ Department of Animal and Poultry Production, Faculty of Agriculture and Natural Resources, Aswan \\ University, Egypt.
}

(Received 3/7/2017, accepted 14/8/2017)

\section{SUMMARY}

$\mathrm{O}$ ne hundred and twenty unsexed one-day-old Cobb broiler chicks were randomly distributed into four groups (5 replicates per group) to study the effect of multienzymes and/or probiotics supplementation on productive performance and nutrients digestibility of broiler chickens. The first group was used as control and fed the basal diet without supplementation, while, chicks in the $2 \mathrm{nd}, 3 \mathrm{rd}$ and 4th groups were fed the basal diet supplemented with multienzymes (Avizyme at $0.20 \mathrm{~g} / \mathrm{kg}$ diet), probiotics (Biacton at $0.50 \mathrm{~g} / \mathrm{kg} \mathrm{diet})$ and multienzymes plus probiotics $(0.20 \mathrm{~g}$ Avizyme $/ \mathrm{kg} \mathrm{diet}+$ $0.50 \mathrm{~g} / \mathrm{kg}$ Biacton), respectively. Body weight (BW), body weight gain (BWG), and feed intake (FI) were recorded. Feed conversion rate (FCR), production index and economical efficiency were calculated. At the end of the experiment a digestibility trial was carried out. Results showed that the chickens fed diet supplemented with multienzymes and probiotics during days 22-35 and 0-35 of age had significantly higher BWG and FI and better FCR followed by those fed diet supplemented with either multienzymes or probiotics compared to those fed control diet. The multienzymes and/or probiotics supplementation had significantly improved the digestibility of dry matter (DM), crude protein (CP) and ether extract (EE) compared to the control. In addition, dietary supplementation with multienzymes plus probiotics or multienzymes alone had significantly improved the digestibility of crude fiber (CF) compared to the control. Chicks fed diet supplemented with multienzymes plus probiotics had significantly better production index and economical efficiency followed by those fed diet supplemented with multienzymes or probiotics alone compared to those fed the control diet. In conclusion: multienzyme and /or probiotics are good growth stimulators to the broiler chicks and can be added together to the diet to improve productive performance and feed utilization.

Keywords: Broiler, multienzymes, probiotics, growth performance, nutrients digestibility.

\section{INTRODUCTION}

The consumption and trade of poultry products are increasing rapidly as the human population increases, making it the second largest source of meat (FAO, 2014). The animal feed industry as a whole has been worked toward solutions to lower costs up front and as a result have a lower cost at the end product for the consumer. Despite there are a several ways to reduce feed cost, the enzymes supplementation (ES) has demonstrated to be an effective way to reduce it. Enzymes not only make the animals able to benefit from the parts of feedstuffs that were not previously utilized, but also allow the nutritionist to change the diet content. The multienzymes allow the producer to lower feed costs while maintaining optimum production rates (Hahn, 2010; Attia et al., 2012, 2014). Also, Plant feedstuffs contain non-starch polysaccharides (NSP), which are indigestible and able to reduce use of nutrients in poultry by lowering their digestion and absorption (Kim et al., 2005). Thus, the presence of NSP in the diet of poultry can also limit the efficiency of nutrient usage. Addition of carbohydrate enzymes in poultry diets may reduce the anti-nutritional effects for NSP. Thus, the ES in poultry diets could improve poultry performance (Peric et al., 2008; Attia et al., 2012, 2014).

Probiotics are live microorganisms (such as bacteria, fungi and yeast) that make a positive impact on the host physiological status. This is frequently accomplished by their capacity to modify the gut 
microbial balance in a helpful way, which thus will enhance the health of animals and birds (Bengmark, 1998; Fuller, 2001).

Nowadays, probiotics have been utilized as a feed additive in diets of poultry to improve performance and immunity (Higgins et al., 2008). Moreover, probiotics addition to poultry diets had positive impacts on growth rate, feed intake (Afsharmanesh and Sadaghi, 2014; Lei et al., 2015), Feed conversion rate (FCR) (Zhang and Kim, 2014) and nutrient digestibility (Li et al., 2008; Zhi-gang et al., 2014; Zhang and Kim, 2014) in broiler chickens. This study aimed to study the effect of multienzymes and/or probiotics supplementation on productive performance and nutrients digestibility of broiler chickens.

\section{MATERIALS AND METHOD}

This study was carried out at the Poultry Farm, Faculty of Agriculture, Damanhour University, Egypt, from March to April, 2017.

One hundred and twenty unsexed one-day old Cobb broiler chicks, obtained from a commercial hatchery, were randomly distributed into four groups with 5 replicates and 6 birds per replicate (i.e., 30 birds per treatment) and reared on same managerial conditions. The first group was used as control and fed only a basal diet without supplementation (T1), while, chicks in the $2^{\text {nd }}, 3^{\text {rd }}$ and $4^{\text {th }}$ groups were fed the basal diet supplemented with multienzymes (Avizyme at $0.20 \mathrm{~g} / \mathrm{kg}$ diet; T2), probiotics (Biacton at $0.50 \mathrm{~g} / \mathrm{kg}$ diet; T3) and multienzymes plus probiotics (0.20 g Avizyme $/ \mathrm{kg}$ diet $+0.50 \mathrm{~g} / \mathrm{kg}$ Biacton; T4), respectively. The enzymes complex preparation Avizyme® 1505 is a product of Danisco Animal Nutrition, Marlborough, Wiltshire, UK., containing 1500 U/g endo-1, 4- $\beta$-xylanase, 2000 U/g $\alpha$-amylase and $20000 \mathrm{U} / \mathrm{g}$ protease and its recommended dose of use in broiler and turkey diets is $0.20 \mathrm{~g}$ per $\mathrm{kg}$ diet. Biacton is a product of Chemvet DK A/S, Denmark. It consists of Lactobacillus farciminis CNCM MA67/4R at a concentration of $1 \times 10^{9} \mathrm{CFU}$ g-1, together with the carrier materials being waxy maize corn starch $(19.8 \%)$, yeast extract $(7.5 \%)$, oil-free soybean lecithin $(2.4 \%)$, and corn starch $(70.1 \%)$ and its recommended dose of use in broiler and turkey diets is $0.5 \mathrm{~kg}$ Biacton per ton feed. The experimental diets were formulated according to NRC (1994) as shown in Table (1). The chicks were housed in wire cages $(60 \times 50 \times 40 \mathrm{~cm})$ in semi-opened room. Chicks were fed the experimental diets ad libtium and given free access to water. A light schedule similar to commercial conditions was applied until the $7^{\text {th }}$ day being $23 \mathrm{~h}$ light followed by $20 \mathrm{~h}$ light from 8-35 days of age. The brooding temperature (indoor) was 32, 30, 27 and 21-24 ${ }^{\circ} \mathrm{C}$ during 1-7, 8-14, 15-20 and 21-35 days of age (declined gradually). Chicks were vaccinated against Newcastle Disease and Infectious Bronchitis. Body weight and feed intake were recorded at 1,21 and 35 days of age, and the body weight gain (BWG, g/chick) and FCR (g feed/g gain) were calculated. Production index value was calculated throughout the experimental period (1-35d of age) as reported by Attia et al. (2012).

$\mathrm{PI}=\mathrm{BW}(\mathrm{kg}) \times \mathrm{SR} /(\mathrm{PP} \times \mathrm{FCR}) \times 100$ Where:

$\mathrm{PI}=$ Production Index $\mathrm{BW}=$ Body weight $(\mathrm{kg})$

$\mathrm{SR}=$ Survival rate $(100 \%-$ mortality $) \mathrm{PP}=$ Production period (days)

$\mathrm{FCR}=$ Feed conversion ratio $(\mathrm{kg}$ feed $/ \mathrm{kg}$ gain)

At 35 days of age the apparent digestibility of nutrients and ash retention were evaluated using five birds per treatment housed individually in metabolic cages by using total collection method as cited by (Abou-Raya and Galal, 1971). Dry matter (DM), crude protein (CP), ether extract (EE), crude fiber (CF) and ash content of the dried excreta as well as those of feed were determined according to AOAC (2004). Economical evaluation for all experimental treatments was made according to Zeweil, (1996).

\section{Statistical analysis}

Data were analyzed by the GLM procedure (Statistical Analysis System (SAS), 2002) using one-way ANOVA with the following model:

$$
\mathrm{Y}_{\mathrm{ik}}=\mu+\mathrm{T}_{\mathrm{i}}+\mathrm{e}_{\mathrm{ik}}
$$

Where $Y$ is the dependent variable; $\mu$ is the general mean; $T_{i}$ is the effect of experimental treatments; $\mathrm{e}_{\mathrm{ik}}$ is the experimental random error.

Before analysis, all percentages were subjected to arcsine transformation $\left(\log _{10} x+1\right)$ to normalize data distribution. The significance of the differences among means was determined using Duncan's new 
Egyptian J. Nutrition and Feeds (2017)

multiple range test (Duncan, 1955) (at $\mathrm{P}<0.05$ ).

Table (1): Ingredients, determined and calculated analysis (\%) of the basal diets

\begin{tabular}{|c|c|c|}
\hline \multirow{2}{*}{ Ingredient } & \multicolumn{2}{|c|}{ Diet $(\%$ as fed $)$} \\
\hline & Starter (1-21 d of age) & Grower (22-35 d of age) \\
\hline Corn, Grain & 53.60 & 56.30 \\
\hline Soybean meal (44\% CP) & 31.00 & 20.00 \\
\hline Wheat Bran & 0.00 & 5.00 \\
\hline Gluten Meal (60\% CP) & 5.00 & 5.00 \\
\hline Full fat soybean seed & 4.00 & 7.00 \\
\hline Vegetable oil & 2.75 & 3.00 \\
\hline Dicalcium phosphate & 1.80 & 1.60 \\
\hline Vit+min premix ${ }^{*}$ & 0.30 & 0.30 \\
\hline Limestone & 1.00 & 1.00 \\
\hline $\mathrm{NaCl}$ & 0.30 & 0.45 \\
\hline DL-Methionine & 0.15 & 0.20 \\
\hline L-Lysine $\mathrm{HCl}$ & 0.10 & 0.15 \\
\hline Total & 100.00 & 100.00 \\
\hline \multicolumn{3}{|c|}{ Determined $^{1}$ and calculated ${ }^{2}$ composition ( $\%$ as fed $)$} \\
\hline Nutrient & Supplied & Supplied \\
\hline Dry matter ${ }^{1}$ & 86.59 & 86.66 \\
\hline $\mathrm{ME}(\mathrm{kcal} / \mathrm{kg})^{2}$ & 3061 & 3107 \\
\hline Crude protein ${ }^{1}$ & 23.16 & 20.56 \\
\hline Ether extract ${ }^{1}$ & 5.88 & 6.83 \\
\hline Crude fiber ${ }^{1}$ & 3.68 & 3.64 \\
\hline Calcium $^{2}$ & 0.91 & 0.85 \\
\hline $\mathrm{Ash}^{1}$ & 6.09 & 5.97 \\
\hline Total Phos. ${ }^{2}$ & 0.74 & 0.71 \\
\hline Available phosphorus ${ }^{2}$ & 0.49 & 0.47 \\
\hline Lysine $^{2}$ & 1.22 & 1.08 \\
\hline Methionine $^{2}$ & 0.55 & 0.56 \\
\hline
\end{tabular}

*Vitamins and minerals mixture provide per kilogram of diet: Vitamin A (as all-trans-retinyl acetate); $12000 \mathrm{IU}$; Vitamin E (all rac- $\alpha$-tocopheryl acetate); $10 \mathrm{IU} ; \mathrm{k}_{3} 3 \mathrm{mg}$; Vit. $D_{3}, 2200 \mathrm{ICU}$; riboflavin, $10 \mathrm{mg}$; Ca pantothenate,10 $\mathrm{mg}$; niacin, $20 \mathrm{mg}$; Choline chloride, $500 \mathrm{mg}$; Vitamin $B_{12}, 10 \mu \mathrm{g}$; Vitamin $B_{6}, 1.5 \mathrm{mg}$; Thiamine (as thiamine mononitrate); $2.2 \mathrm{mg}$; Folic acid, $1 \mathrm{mg} ;$ D-biotin, $50 \mu \mathrm{g}$. Trace mineral (milligrams per kilogram of diet) $\mathrm{Mn}, 55 ; \mathrm{Zn}$, 50; $\mathrm{Fe}, 30 ; \mathrm{Cu}, 10 ; \mathrm{Se}, 0.1$ and Ethoxyquin $3 \mathrm{mg}$.

\section{RESULTS AND DISCUSSION:}

\section{Growth performance}

The growth performance of broilers fed diet supplemented with multi-enzymes and/or probiotics during 1-35 days of age is shown in Table 2. The chicks in T4 group fed MEnz+ Pro had significantly heavier BWG during the period from 0-21 days of age than chicks in T1, T2 and T3 groups. Meanwhile, BWG of Chicks in T4 was significantly the highest during the periods 22-35 and 0-35 days of age followed by those in T2 and T3 compared to those in T1. Moreover, the chicks in T4 consumed significantly higher in feed intake during 22-35 and 0-35 days of age than chicks in T1, T2 and T3 without significant differences between T1, T2 and T3. However, feed intake during 0-21 days of age was insignificantly affected by treatments. In addition, the chicks in T3 and T4 have significantly better FCR during the period 0-21 days of age than chicks in T1 without any difference between T1 and T2 groups. Also, the chicks in T4 had significantly better in FCR during 22-35 days of age than chicks in T1 without significant differences between T1, T2 and T3. However, the chicks in T2, T3 and T4 had significantly better in FCR during the whole period than chicks in T1 without significant differences between T2, T3 and T4 (Table 2). The present results are in agreement with those reported by Persia et al. (2002); AlHarthi (2006) and Attia et al. (2008, 2012, 2014). In this regard, Peric et al. (2008); Raza et al. (2009); Abdollahi et al. (2016) and Amerah et al. (2017) concluded that enzymes supplement (ES) increased BWG and improved FCR of broiler chicken. In addition, Sherif (2009a) observed a positive effect for 
adding different types of enzyme preparations in the grower-finisher diets of broilers, on final BW, and BWG. In another study, Sherif (2009b) found that dietary supplementation with different ES improved FCR for broiler chicks fed plant protein diets. Moreover, Zhou et al. (2009) suggested that ES in broiler chicken diets could improve the efficiency of energy utilization, especially in low metabolizable energy diets. Sun et al. (2015) indicated that ES increased BWG and improved FCR from 0 to $14 \mathrm{~d}$ and from 0 to 21 days of age. In this respect, supplementation of exogenous enzymes in poultry diets increased BWG and FI and improved FCR as compared to poultry diets in which enzyme was not supplemented during day 1-21and 1-35 (Mahmood et al., 2017). In the literature, the improvements in growth rate, FCR and economic traits due to supplementation of multi-enzymes were attributed to the enhancement in the availability and absorption of nutrients through increasing the digestibility of the ingested diets (Abudabos, 2012; Nourmohammadi et al., 2012; Attia 2014). In addition, multienzyme containing amylase, xylanase and protease was found to improve energy utilization in corn-SBM and sorghum-SBM diets due to the breakdown of starch, cereal cell walls, and endogenous proteins (Hong et al., 2002; Attia et al., 2008). Similarly, Cowieson et al. (2003) and Ghazalah et al. (2005) showed that the improvement in BWG obtained upon feeding enzyme mixtures may be attributed to the presence of amylase and NSPs degrading enzymes in enzymes mixture, rather than protease, that making the nutrients more available to the birds and improve chick's growth performance.

Supplementation of probiotics to poultry diets increased broiler growth (Shoeib and Madian, 2002; Willis et al., 2007; Sherief et al., 2012; Zhi-gang et al., 2014; Zhang and Kim, 2014), feed intake (Landy and Kavyani, 2013; Afsharmanesh and Sadaghi, 2014) and improve FCR (Shim et al., 2012; Zhang and Kim, 2014) as compared to poultry diets without supplementation. In addition, Timmerman et al. (2006) observed that broilers given drinking water supplemented with chicken specific probiotic had a productivity index, taking into account daily BWG, FCR and mortality, superior to that of the nonsupplemented birds. Sherief et al. (2012) recorded that probiotic addition increased $(\mathrm{P}<0.05)$ the final BW, BWG and FI and improved FCR of broiler chickens compared with those fed the control diet. In this regard, Dersjant-Li et al. (2015) suggested that multi-enzymes plus probiotics supplementation increased FI and improved BWG and production efficiency in broilers under commercial settings. The improvement in growth rate in the probiotic treated birds was associated with increased FI (Landy and Kavyani, 2013; Lei et al., 2015) and improved FCR (Shim et al., 2012; Zhang and Kim, 2014) compared with untreated birds. Therefore, increased digestibility of feed resulting in improved FCR could be one of mode of actions for improved growth rate. The improvement in performance and productivity of poultry due to the probiotics addition in diets has been attributed to increased FI and improved FCR (Shim et al., 2012).

Table (2): Performance of broilers fed diet supplemented with multienzymes and/or probiotics.

\begin{tabular}{|c|c|c|c|c|c|c|}
\hline Items & $\begin{array}{c}\text { Control } \\
\text { (T1) }\end{array}$ & $\begin{array}{l}\text { MEnz } \\
\text { (T2) }\end{array}$ & $\begin{array}{l}\text { Prob } \\
\text { (T3) }\end{array}$ & $\begin{array}{c}\text { MEnz+Pro } \\
\text { (T4) }\end{array}$ & SEM & Sig \\
\hline \multicolumn{7}{|l|}{ Body weight gain $(\mathrm{g})$ : } \\
\hline $0-21 d$ & $716 b$ & $740 \mathrm{~b}$ & $737 b$ & $778 \mathrm{a}$ & 2.05 & 0.001 \\
\hline $22-35 d$ & $907 \mathrm{c}$ & $973 b$ & $991 b$ & $1089 a$ & 45.02 & 0.008 \\
\hline $0-35 d$ & $1623 c$ & $1713 b$ & $1728 b$ & $1867 \mathrm{a}$ & 44.35 & 0.006 \\
\hline \multicolumn{7}{|l|}{ Feed intake $(\mathrm{g})$ : } \\
\hline $0-21 d$ & 1079 & 1076 & 1049 & 1089 & 21.39 & 0.617 \\
\hline $22-35 d$ & $1702 b$ & $1717 b$ & $1745 b$ & $1850 \mathrm{a}$ & 19.56 & 0.003 \\
\hline $0-35 d$ & $2780 \mathrm{~b}$ & $2793 b$ & $2794 b$ & $2939 a$ & 29.52 & 0.005 \\
\hline \multicolumn{7}{|c|}{ Feed conversion ratio ( $\mathrm{g}$ feed/g gain): } \\
\hline $0-21 d$ & $1.51 \mathrm{a}$ & $1.42 \mathrm{ab}$ & $1.39 \mathrm{~b}$ & $1.38 \mathrm{~b}$ & 0.032 & 0.041 \\
\hline $22-35 d$ & $1.88 \mathrm{a}$ & $1.81 \mathrm{ab}$ & $1.80 \mathrm{ab}$ & $1.72 b$ & 0.043 & 0.117 \\
\hline $0-35 d$ & $1.71 \mathrm{a}$ & $1.63 b$ & $1.62 b$ & $1.57 \mathrm{~b}$ & 0.025 & 0.009 \\
\hline
\end{tabular}

$\overline{a, b, c, d}$ Means in the same row followed by different letters are significantly different at $(p \leq 0.05)$; MEnz $=$ Multienzyme; Prob= Probiotics; MEnz+Pro =Multi-enzyme+ Probiotics; SEM=Standard error of mean. 


\section{Nutrients digestibility (\%)}

Data presented in Table 3 showed the effect of supplementing multi-enzymes and/or probiotics to experimental diets on the nutrients digestibility and ash retention of broiler chicks. The digestibility of nutrients in groups T2, T3 and T4 were significantly better for crude protein, ether extract and dry matter digestibility than T1 without any significant differences between T2, T3 and T4. Moreover, chicks in T2 and T4 had significantly greater digestibility of crude fiber than chicks in T1. However, apparent ash retention was insignificantly affected by treatments. These results agree with the findings of Sherif (2009a), who found that adding different types of commercial enzyme preparations to broiler diets had a positive impact on the digestibility of $\mathrm{CP}$ and $\mathrm{EE}$, and nitrogen retention as compared to those fed the control diets. Similarly, Sherif (2009b) reported that digestibility of DM of boiler chicks were improved in response to adding ES (Avian plus and Natuzyme) to their diets. In addition, Wang et al. (2005) demonstrated that apparent CP digestibility in broiler chicks increased in response to feeding diets supplemented with enzymes. Amerah et al. (2017) concluded that ES improved nutrient digestibility of broiler chicken. The improvement in starch digestibility was associated with the augmentation of endogenous $\alpha$-amylase and improvement each of digestion resistant starches, access to cell resistant starches and access to cell contents via a reduction in cell wall integrity. In addition to the benefit effects with corn, amylase, xylanase and protease that have additional benefit effects with soybean meal. These benefits when apply to corn and soybean meal, as the protease component of the enzyme combination can have a positive effect on trypsin inhibitor (Cowieson and Ravindran, 2008). Supporting this, energy and amino acids digestibility of a corn-soy based diet could be improved by nearly $3 \%$ when supplemented with xylanase, amylase and protease (Cowieson and Ravindran, 2008). The combination of amylase, xylanase and protease can also improve ileal digestibility by $2 \%$ (Cowieson and Ravindran, 2008). Also, Cowieson and Adeola (2005) concluded that combination of phytase and xylanase, amylase and protease improved ileal digestibility by a factor greater than $100 \mathrm{kcal} / \mathrm{kg}$ diet. Similar results were also reported by Fuller (1997); Palliyaguru et al. (2004); Zhi-gang et al. (2014) who detected improvements of CP retention in broilers at the starter phase of growth when supplementing the diet with $0.02 \%$ probiotics. This effect may be mediated by an improvement in the main functions of digestion and absorption in the gut (Fioramonti et al., 2003). These findings suggested that part of the beneficial impacts of probiotics on early phase of growth performance may be mediated via improvement in the apparent retention of CP through reducing nitrogen excretion. Probiotics can also enhance the synthesis of some vitamins, raised digestive enzymes and increasing the volatile fatty acids production that beneficial for the animals (Fuller, 2001). They may also raise the efficiency of nutrient usage through enhancing the gut health resulting in higher activities of gut enzymes and nutrient availability (Fuller, 2001) and increase the absorption of nutrients from gut through their indirect impact on its permeability (Higgins et al., 2008).

Table (3): The apparent digestibility of the nutrients and ash retention (\%) of broilers fed diets supplemented with multi-enzyme and/or probiotics.

\begin{tabular}{|c|c|c|c|c|c|c|}
\hline Items & $\begin{array}{c}\text { Control } \\
\text { T1 }\end{array}$ & $\begin{array}{c}\text { MEnz } \\
\text { T2 }\end{array}$ & $\begin{array}{c}\text { Prob } \\
\text { T3 }\end{array}$ & $\begin{array}{c}\text { MEnz+Pro } \\
\text { T4 }\end{array}$ & SEM & Sig \\
\hline Crude protein & $63.9 \mathrm{~b}$ & $73.5 \mathrm{a}$ & $73.5 \mathrm{a}$ & $76.9 a$ & 1.121 & 0.006 \\
\hline Ether extract & $66.2 b$ & $76.6 \mathrm{a}$ & $76.7 \mathrm{a}$ & $78.9 \mathrm{a}$ & 1.038 & 0.001 \\
\hline Crude fiber & $16.6 \mathrm{~b}$ & $19.0 \mathrm{a}$ & $17.9 \mathrm{ab}$ & $19.6 \mathrm{a}$ & 0.582 & 0.008 \\
\hline Ash retention & 29.0 & 33.5 & 33.8 & 35.1 & 1.621 & 0.072 \\
\hline Dry matter & $67.2 \mathrm{~b}$ & $72.0 \mathrm{a}$ & $72.4 \mathrm{a}$ & $72.0 \mathrm{a}$ & 0.882 & 0.001 \\
\hline
\end{tabular}

${ }^{a, b}$ Means in the same row followed by different letters are significantly different at $(p \leq 0.05) ;$ MEnz $=$ Multi-enzyme; Prob $=$ Probiotics; MEnz+Pro $=$ Multi-enzyme + Probiotics $;$ SEM=Standard error of mean .

\section{Economic efficiency and Production Index}

The chicks in T4 had significantly higher feed cost, total costs, total revenue and net revenue during the whole period than chicks in T1, T2 and T3 without any differences in feed cost and total costs between T1, T2 and T3 (Table 4). Moreover, chicks in T2 and T3 had significantly higher in total revenue and net revenue during the whole period than chicks in $\mathrm{T} 1$ without any difference in total revenue and net revenue between T2 and T3. On the other hand, Chicks fed MEnz+Pro (T4) had significantly better economical efficiency followed by those in T3 then T2, compared to those in T1. Moreover, Chicks of T4 had significantly better production index followed by those of $\mathrm{T} 2$ and $\mathrm{T} 3$, compared to $\mathrm{T} 1$. These results are similar to those reported by Jahan et al. (2006) and Attia et al. (2014) who indicated that production 
index and economical efficiency increased with supplementing multienzyme to the diets compared with control diets. Also, Osman (2003) and Zeweil et al. (2006) reported that, probiotic addition to diet improved economical efficiency as compared with control diet. This improvement could be due to improving BW and FCR. The same result was confirmed by Mostafa et al. (2015) who indicated that economical efficiency increased with supplemented ES (Bio-Mos) diets compared with their control. In conclusion: Multienzyme and /or probiotics are good growth stimulators to the broiler chicks and can be added together to the diet to improve productive performance and feed utilization.

Table (4): Economical efficiency and production index of broilers fed diets supplemented with multienzymes and/or probiotics

\begin{tabular}{|c|c|c|c|c|c|c|}
\hline Item & $\begin{array}{c}\text { Control } \\
\mathrm{T} 1\end{array}$ & $\begin{array}{l}\text { MEnz } \\
\text { T2 }\end{array}$ & $\begin{array}{c}\text { Prob } \\
\text { T3 }\end{array}$ & $\begin{array}{c}\text { MEnz+Pro } \\
\text { T4 }\end{array}$ & SEM & Sig \\
\hline Feed cost & $11.12 b$ & $11.45 b$ & $11.46 b$ & $12.34 \mathrm{a}$ & 0.123 & 0.001 \\
\hline Total cost & $22.12 b$ & $22.45 b$ & $22.46 b$ & $23.34 \mathrm{a}$ & 0.123 & 0.002 \\
\hline Total revenue & $26.75 c$ & $28.21 \mathrm{~b}$ & $28.45 b$ & $30.65 \mathrm{a}$ & 0.341 & 0.006 \\
\hline Net revenue & $4.628 \mathrm{c}$ & $5.761 b$ & $5.989 b$ & $7.313 \mathrm{a}$ & 0.349 & 0.001 \\
\hline Economic efficiency & $20.94 \mathrm{c}$ & $25.67 \mathrm{cb}$ & $26.67 \mathrm{ab}$ & $31.34 \mathrm{a}$ & 1.585 & 0.003 \\
\hline Production Index & $279 c$ & $309 b$ & $314 b$ & $348 \mathrm{a}$ & 7.757 & 0.001 \\
\hline
\end{tabular}

\section{REFERENCES}

Abdollahi, M. R., B. J. Hosking, D. Ning and V. Ravindran (2016). Influence of palm kernel meal inclusion and exogenous enzyme supplementation on growth performance, energy utilization, and nutrient digestibility in young broilers. Asian Australas. J. Anim. Sci. 29(4): 539-548.

Abou-Raya, A. K. and A. Gh. Galal (1971). Evaluation of poultry feeds in digestion trials with reference to some factors involved. UAR (Egypt) Anim. Prod. 11: 207-221.

Abudabos, M. A. (2012). Phytate phosphorus utilization and intestinal phytase activity in laying hens. Ital. J. Anim. Sci. 2012; 11: e8 doi:10.4081/ijas.2012.e8

Afsharmanesh, M. and B. Sadaghi (2014). Effects of dietary alternatives (probiotic, green tea powder and Kombucha tea) as antimicrobial growth promoters on growth, ileal nutrient digestibility, blood parameters, and immune response of broiler chickens. Comp. Clin. Pathol. 23(3): 717-724.

AI-Harthi, M. A. (2006). Impact of supplemental feed enzymes, condiments mixture or their combination on broiler performance, nutrients digestibility and plasma constituents. Inter. J. Poult. Sci. 5: 764-771.

Amerah, A. M., L. F. Romero, A. Awati and V. Ravindran (2017). Effect of exogenous xylanase, amylase, and protease as single or combined activities on nutrient digestibility and growth performance of broilers fed corn/soy diets. Poult. Sci. 96:807-816.

AOAC. (2004). Official methods of analysis. $18^{\text {th }}$ ed., Assoc. of Off. Anal. Chem., Washington, DC, USA.

Attia, Y. A., W. S. El-Tahawy, A. E. Abd El-Hamid, A. Nizza, F. Bovera, M. A. Al-Harthi and M. I. ElKelaway (2014). Effect of feed form, pellet diameter and enzymes supplementation on growth performance and nutrient digestibility of broiler during days 21-37 of age. Arch Tierz. 57:1-11.

Attia, Y. A., W. S. El-Tahawy, A. E. Abd El-Hamid, S. S. Hassan, A. Nizza and M. I. El-Kelawy (2012). Effect of phytate with or without multienzyme supplementation on performance and nutrient digestibility of young broiler chicks fed mash or crumble diets. Ital. J. Anim. Sci. 11: 303-308.

Attia, Y.A., A. E. Tag El-Din, H. S. Zeweil, A. S. Hussein, E. S. Qota and M. A. Arafat (2008). The effect of supplementation of enzyme on laying and reproductive performance in Japanese quail hens fed Nigella seed meal. J. Poult. Sci. 45: 110-115. 
Bengmark, S. (1998). Ecological control of the gastrointestinal tract: The role of probiotic flora. Gut. 42: 2-7.

Cowieson, A. J. and O. Adeola (2005). Carbohydrases, protease, and phytase have an additive beneficial effect in nutritionally marginal diets for broiler chicks. Poult. Sci. 84:1860-1867.

Cowieson, A. J. and V. Ravindran (2008). Effects of exogenous enzymes in maize-based diets varying in nutrient density for young broilers; growth performance and digestibility of energy, minerals and amino acids. Br. Poult. Sci. 49:34-44.

Cowieson, A. J., T. Acamovic and M. R. Bedford (2003). The effects of phytase and phytic acid on the loss of endogenous amino acids and minerals from broiler chickens. Br. Poult. Sci. 45:101-108.

Dersjant-Li Y., K. van de Belt, J. van der Klis, H. Kettunen, T. Rinttilä and A. Awati (2015). Effect of multi-enzymes in combination with a direct-fed microbial on performance and welfare parameters in broilers under commercial production settings. J. Appl. Poult. Res. 24:80-90.

Duncan, D.B. (1955). Multiple range test and multiple F-tests. Biometrics. 11: 1-42.

FAO, (2014). Meat and Meat Products. http://www.fao.org/ag/againfo/themes/en/meat/home.html Accessed 18 December 2014.

Fioramonti, J., V. Theodorou and L. Bueno (2003). Probiotics and their effect on gut physiology. Best Pract. Res. Clin. Gastroenterol. 17: 711-24.

Fuller, R. (2001). The chicken gut microflora and probiotic supplements. J. Poult. Sci. 38: 189-196.

Fuller, R. (1997). Probiotics 2. Application and Practical aspects. Published by Chapman and Hall London, U.K: 1-209.

Ghazalah, A.A., A. H. Abd EI-Gawad, M.S. Soliman and Amany W. Youssef (2005). Effect of enzyme preparation on performance of broilers fed corn-soybean meal based diets. Egypt. Poult. Sci. J. 25: 295-316.

Hahn Dana, L. (2010). The effects of phytase and an enzyme combination in moderate and low nutrient dense diets in laying hens. M.Sc. Thesis University of Nebraska-Lincoln,

Higgins, S. E., J. P. Higgins, A. D. Wolfenden, S. N. Henderson, A. Torres-Rodriguez, G. Tellez and H. Hargis. (2008). Evaluation of a Lactobacillus-based probiotic culture for the reduction of Salmonella enteritis in neonatal broiler chicks. Poult. Sci. 87:27-31.

Hong, D., H. Burrows and O. Adeola (2002). Addition of enzyme to starter and grower diets for ducks. Poult. Sci. 81:1842-1849.

Jahan, M. S., M. Asaduzzaman and A. K. Sarkar (2006). Performance of broiler fed on mash, pellet and crumble. Inter. J. of Poult. Sci. 5(3): 265-270.

Kim, J. C.; Simmins, P. H.; Mullan, B. P. and J. R. Pluske (2005). The digestible energy value of wheat for pigs, with special reference to the post-weaned animal. Anim. Feed Sci. Technol. 122: 257-287.

Landy, N. and A. Kavyani (2013). Effects of using a multi-strain probiotic on performance, immune responses and caecal microflora composition in broiler chickens reared under cyclic heat stress condition. Iran. J. of Appl. Anim. Sci. 3(4): 703-708.

Lei, X., X. Piao, Y. Ru, H. Zhang, A. Péron and H. Zhang (2015). Effect of Bacillus amyloliquefaciensbased direct-fed microbial on performance, nutrient utilization, intestinal morphology and cecal microflora in broiler chickens. Asian-Austr. J. Anim. Sci. 28(2): 239-246.

Li, X. L. Q. Liu and C. L. Xu (2008). Effects of supplementation of fructo-oligosaccharide and/or Bacillus Subtilis to diets on performance and intestinal microflora in broilers. Archiv für Tierzucht, 51: 64-70.

Mahmood, T., M. A. Mirza, H. Nawaz, M. Shahid, M. Athar and M. Hussain (2017). Effect of supplementing exogenous protease in low protein poultry by-product meal based diets on growth performance and nutrient digestibility in broilers. Anim. Feed Sci. and Tech. 228: 23-31.

Mostafa, M. M. E., H. A. Thabet and M. A. M. Abdelaziz (2015). Effect of Bio-Mos Utilization in Broiler Chick Diets on Performance, Microbial and Histological Alteration of Small Intestine and Economic Efficiency. Asian J. Anim. and Vet. Adv., 10: 323-334. 


\section{El-Kelawy et al.}

NRC. (1994). Nutrient Requirements of Poultry, 9th rev. ed. Nat. Acad. Sci.., Washington, DC, USA.

Nourmohammadi, R., S. M. Hosseini, H. Farhangfar and M. Bashtani (2012). Effect of citric acid and microbial phytase enzyme on ileal digestibility of some nutrients in broiler chicks fed corn-soybean meal diets. Ital. J Anim Sci 11:e7, 2012, doi:10.4081/ijas.2012.e7

Osman, Mona (2003). The influence of probiotic inclusion on the productive performance of commercial layers. Egypt. Poult. Sci. 23 (2): 283-297.

Palliyaguru, M. W., N. Priyankarage, S. S. Silva, S. P. Gunaratne, W. M. Weerasinghe, P. S. Fernadoand and M.H. Attapatu (2004). Effect of different probiotics on nutrient utilisation and intestinal microflora of broiler chickens. Spring Meeting of the WPSA UK Branch-Posters. 58-59.

Peric, L., N. Miloševic, M. Dukic-Stojcic, S. Bjedov and V. Rodic (2008). Effect of enzymes on performances of broiler chickens. Biotechnol. Anim. Husband., 24 (5-6): 45-51.

Persia, M. E., B. A. Dehority and M. S. Lilburn (2002). The effects of enzyme supplementation of cornand wheat-based diets on nutrient digestion and cecal microbial populations in turkeys. J. of Appl. Poult. Res. 11: 134-145.

Raza, S., M. Ashraf, T. N. Pasha and F. Latif (2009. Effect of enzyme supplementation of broiler diets containing varying level of sunflower meal and crude fiber. Pak. J. of Bot. 41(5):2543-2550

SAS Institute (2002). SAS/STAT User's guide statistics. SAS institute INC., Cary. NC, USA.

Sherif, Kh. El. (2009a). Performance of broiler chicks fed plant protein diets supplemented with commercial enzymes. J. Agric. Sci., Mansoura Univ., 34 (4): 2819-2834.

Sherif, Kh. El. (2009b). Effect of using probiotics and enzymes with plant protein diets in broiler performance. J. Agric. Sci., Mansoura Univ., 34 (5): 4493-4505.

Sherief, M. A., M. S. A. Sherief and M. A. H. Khaled. 2012. The Effects of Prebiotic, Probiotic and Synbiotic Supplementation on Intestinal Microbial Ecology and Histomorphology of Broiler Chickens. JAVMS, 6(4): 277-289

Shim, Y., S. Ingale, J. Kim, K. Kim, D. Seo, S. Lee, B. Chae and I. Kwon (2012). A multi-microbe probiotic formulation processed at low and high drying temperatures: effects on growth performance, nutrient retention and caecal microbiology of broilers. Br. Poult. Sci. 53(4): 482-490.

Shoeib, H. K. and A. H. Madian (2002). A study on the effect of feeding diets containing probiotics (Pronifer and biogen) on growth performance, intestinal flora and haematological picture of broiler chicks. Assiut Vet. Med. J., 47: 112-125.

Sun, Q., D. Liu, Sh. Guo, Y. Chen and Y. Guo (2015). Effects of dietary essential oil and enzyme supplementation on growth performance and gut health of broilers challenged by Clostridium perfringens. Anim. Feed Sci. Tech. 207: 234-244.

Timmerman, H.M., A. Veldman, E. van den Elsen, F. M. Rombouts and A. C. Beynen (2006). Mortality and growth performance of broilers given drinking water supplemented with chicken-specific probiotics. Poult. Sci., 85: 1383-1388.

Wang, Z. R., S. Y. Qiao, W. Q. Lu and D. F. Li (2005). Effects of enzyme supplementation on performance, nutrient digestibility, gastrointestinal morphology, and volatile fatty acid profiles in the hindgut of broilers fed wheat-based diets. Poult. Sci. 84:875-881.

Willis, W. L., O. S. Isikhuemhen and S. A. Ibrahim (2007). Performance assessment of broiler chickens given mushroom extract alone or in combination with probiotics. Poult. Sci. 86:1856-1860.

Zeweil, H. S. (1996). Enzyme supplements to diets growing Japanese quails. Egypt. Poult. Sci. J., 16: 535-557.

Zeweil, H. S., S. G. Genedy and M. Bassiouni (2006). Effect of probiotic and medicinal plant supplements on the production and egg quality of laying Japanese quail hens. EPC XII Eur. Poult. Conf., Verona, Italy, 62-67

Zhang, Z. and I. Kim (2014). Effects of multistrain probiotics on growth performance, apparent ileal nutrient digestibility, blood characteristics, cecal microbial shedding, and excreta odor contents in broilers. Poult. Sci. 93(2): 364-370. 
Zhi-gang, T., M. Naeem, W. Chao, W. Tian and Zh. Yan-min (2014). Effect of dietary probiotics supplementation with different nutrient density on growth performance, nutrient retention and digestive enzyme activities in broilers. The J. of Anim. \& Plant Sci. 24(5): 1309-1315.

Zhou, Y., Z. Jiang, D. Lv and T. Wang (2009). Improved energy-utilizing efficiency by enzyme preparation supplement in broiler diets with different metabolizable energy levels. Poult. Sci., 88: 316-322.

\title{
تأثير إضافات مخلوط الإنزيمات و/ أو البروبيوتك على الأداء الإنتاجي وهضم المركبات الغذائية في دجاج اللحم.
}

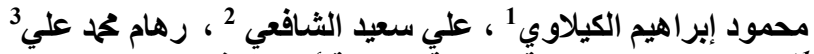

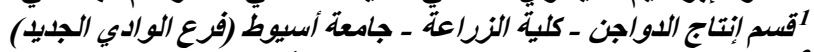

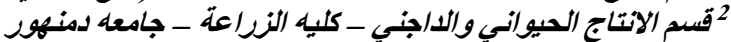 \\ قُسم إنتاج الحيوان والدواجن ـ كلية النزراعة والموارد الطبيعية - جامعة أسوان
}

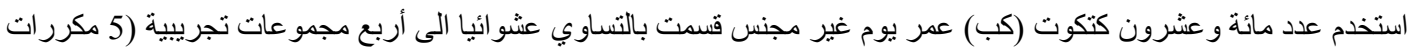

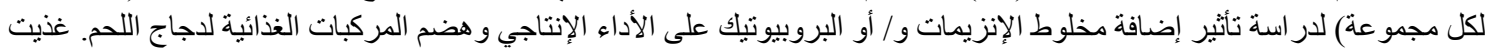

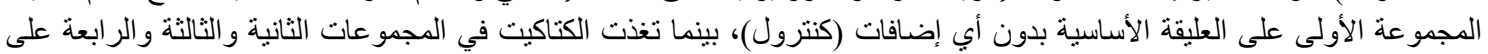

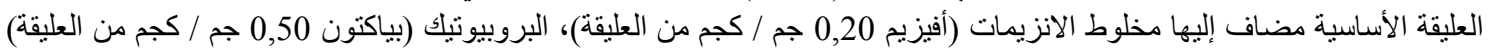

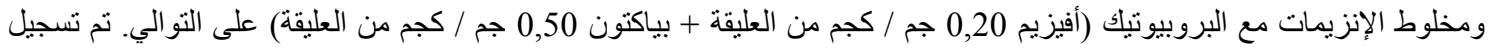

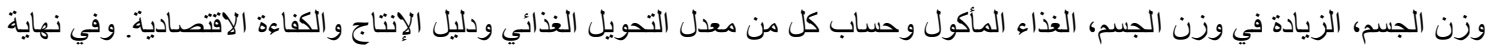

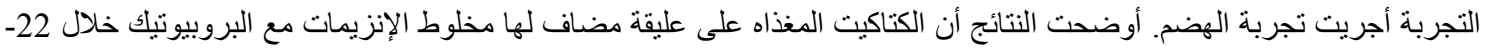

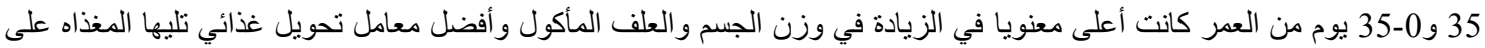

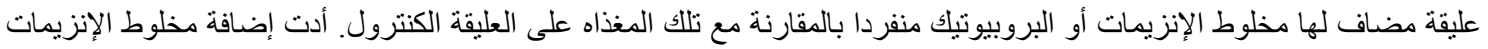

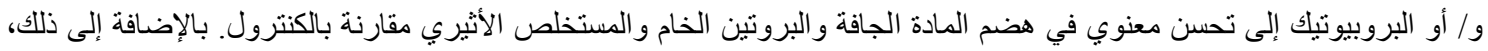

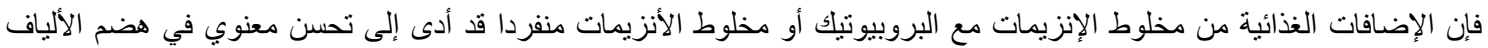

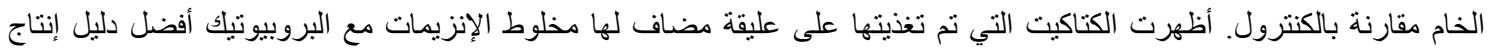

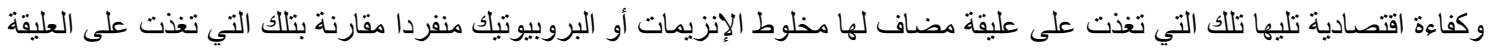

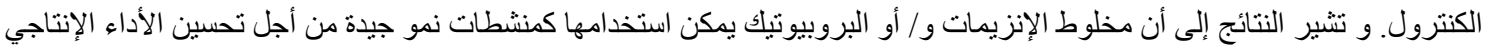
و الاستفادة من الغذاء في علائق دجاج اللحم. 